\title{
Growth, ethanol production, and inulinase activity on various inulin substrates by mutant Kluyveromyces marxianus strains NRRL Y-50798 and NRRL Y-50799
}

\author{
Luz Ángela Galindo-Leva ${ }^{1} \cdot$ Stephen R. Hughes $^{2} \cdot J^{\text {Juan Carlos López-Núñez }}{ }^{3} \cdot$ \\ Joshua M. Jarodsky ${ }^{1}$ Adam Erickson ${ }^{1} \cdot$ Mitchell R. Lindquist ${ }^{2} \cdot$ Elby J. Cox $^{2}$ • \\ Kenneth M. Bischoff ${ }^{2} \cdot$ Eric C. Hoecker $^{2} \cdot$ Siqing Liu $^{2} \cdot$ Nasib Qureshi ${ }^{2}$. \\ Marjorie A. Jones ${ }^{1}$
}

Received: 10 November 2015 / Accepted: 11 April 2016 / Published online: 29 April 2016

(C) The Author(s) 2016. This article is published with open access at Springerlink.com

\begin{abstract}
Economically important plants contain large amounts of inulin. Disposal of waste resulting from their processing presents environmental issues. Finding microorganisms capable of converting inulin waste to biofuel and valuable co-products at the processing site would have significant economic and environmental impact. We evaluated the ability of two mutant strains of Kluyveromyces marxianus ( $\mathrm{Km} 7$ and $\mathrm{Km} 8$ ) to utilize inulin for ethanol production. In glucose medium, both strains consumed all glucose and produced $0.40 \mathrm{~g}$ ethanol/g glucose at $24 \mathrm{~h}$. In inulin medium, $\mathrm{Km} 7$ exhibited maximum colony forming units $(\mathrm{CFU}) / \mathrm{mL}$ and produced $0.35 \mathrm{~g}$ ethanol $/ \mathrm{g}$ inulin at $24 \mathrm{~h}$, while $\mathrm{Km} 8$ showed maximum $\mathrm{CFU} / \mathrm{mL}$ and produced
\end{abstract}

Mention of trade names or commercial products in this article is solely for the purpose of providing specific information and does not imply recommendation or endorsement by the United States Department of Agriculture. USDA is an equal opportunity provider and employer.

Electronic supplementary material The online version of this article (doi:10.1007/s10295-016-1771-5) contains supplementary material, which is available to authorized users.

Stephen R. Hughes

stephen.hughes@ars.usda.gov

1 Department of Chemistry, Illinois State University, Normal, IL 61790-4160, USA

2 United States Department of Agriculture (USDA) Agricultural Research Service (ARS) National Center for Agricultural Utilization Research (NCAUR) Renewable Product Technology Research Unit, 1815, North University Street, Peoria, IL 61604, USA

3 National Coffee Research Centre (Cenicafe) National Federation of Coffee Growers of Colombia (FNC), Cenicafé Planalto Km 4 vía Antigua Chinchiná, Manizales, Caldas, Colombia
$0.02 \mathrm{~g}$ ethanol/g inulin at $96 \mathrm{~h}$. At $24 \mathrm{~h}$ in inulin + glucose medium, $\mathrm{Km} 7$ produced $0.40 \mathrm{~g}$ ethanol $/ \mathrm{g}$ (inulin + glucose) and $\mathrm{Km} 8$ produced $0.20 \mathrm{~g}$ ethanol/g (inulin + glucose) with maximum CFU/mL for $\mathrm{Km} 8$ at $72 \mathrm{~h}, 40 \%$ of that for $\mathrm{Km} 7$ at $36 \mathrm{~h}$. Extracellular inulinase activity at $6 \mathrm{~h}$ for both $\mathrm{Km} 7$ and $\mathrm{Km} 8$ was 3.7 International Units (IU)/mL.

Keywords Kluyveromyces marxianus · Inulin · Inulinase · Coffee waste fermentation $\cdot$ Biorefinery platform

\section{Introduction}

Inulin is a major storage carbohydrate present in more than 36,000 species of plants, including wheat, onion, bananas, garlic, asparagus, sunchoke, chicory, Jerusalem artichoke, dahlia, and yacón $[3,26]$. In these plants, inulin is used as an energy reserve and for regulating cold resistance [36]. Inulin consists of linear chains of $\beta$-2,1-linked D-fructofuranose molecules terminating at the reducing end in a glucose residue linked by an $\alpha-1,2$ bond, as in sucrose [36]. Inulinases catalyze the hydrolysis of the glycosidic linkages in inulin to produce fructose, glucose, and inulooligosaccharides, yielding up to 95-98 \% fructose. Exoinulinases release fructose from the fructosyl terminal, while endo-inulinases act on the internal glycosidic linkages [26]. Inulin is used as a substrate in industrial fermentation processes and in food, feed, biofuel, pharmaceutical, and chemical industries because it is a relatively cheap and abundant source for the microbiological production of ultra-high-fructose syrup, bioethanol, inulo-oligosaccharides, single-cell protein, citric acid, butanediol, and lactic acid $[3,7,18,27,29,33,38]$. The widespread occurrence of inulin in plants results in large amounts of this polysaccharide being found in fruit and vegetable waste worldwide 
[1]. This waste is a potential source of value-added coproducts in a biorefinery platform at the fruit or vegetable processing site.

Kluyveromyces marxianus is a homothallic hemiascomycete yeast frequently isolated from dairy environments. It possesses phenotypic traits, such as the ability to utilize a wide range of carbohydrate substrates, secretion of lytic enzymes, notable thermotolerance and the fastest growth rate of any eukaryotic microbe, that make this yeast attractive for industrial production of ethanol from inexpensive substrates [14, 15, 17]. Because K. marxianus can produce both active inulinase and ethanol, inulin can be fermented directly to ethanol, and, although $K$. marxianus has poorer ethanol tolerance than Saccharomyces cerevisiae [3], it can tolerate ethanol concentrations of more than $100 \mathrm{~g} / \mathrm{L}$ [7]. To clarify the utilization capability of sucrose, raffinose and inulin and the glucose effect on inulinase in $K$. marxianus DMKU 3-1042, Lertwattanasakul et al. [17] examined the growth and metabolite profiles of this strain on these substrates. These investigators determined that raffinose and inulin consumption was reduced by glucose at $30{ }^{\circ} \mathrm{C}$ but almost no glucose repression was observed at $45{ }^{\circ} \mathrm{C}$. An increase in glucose concentration had no effect on sucrose utilization. These sugar-specific glucose effects were consistent with the level of inulinase activity $[6,17]$. investigated the effects of carbon sources, oxygenation, and ethanol on the production of inulinase by $K$. marxianus YX01. Their results showed that glucose repressed inulinase production at $30{ }^{\circ} \mathrm{C}$, while inulin induced inulinase production. Increasing ethanol concentration repressed cell growth but did not affect activity of secreted inulinase [6]. Further studies by Gao and co-workers [7] were performed to investigate differences in gene expression between high and low inulin concentrations and from anaerobic conditions to microaeration. They determined that the differentially expressed genes were mainly associated with the pathways of central carbon metabolism and ethanol formation. Increased inulinase expression was one factor in ensuring efficient fermentation [7].

Yuan et al. [38] studied the Jerusalem artichoke (Helianthus tuberosus), which contains 11-20\% carbohydrates, $70-90 \%$ of which is inulin, as an alternative feedstock for fuel ethanol production using $K$. marxianus ATCC8554. Jerusalem artichoke grows well in non-fertile land and resists many plant pests and diseases. Thus, it does not compete with grain crops for arable land and also benefits ecological environment protection. The growth and ethanol fermentation of $K$. marxianus ATCC8554 were studied using as substrate Jerusalem artichoke grown in saline soil and irrigated with a mixture of freshwater and seawater. The optimum temperatures were $38{ }^{\circ} \mathrm{C}$ for growth and inulinase production, and $35{ }^{\circ} \mathrm{C}$ for ethanol fermentation [38]. Hu and co-workers [10] investigated 87 yeast strains for inulin utilization, extracellular inulinase activity, and ethanol fermentation from both inulin and Jerusalem artichoke tuber flour at $40{ }^{\circ} \mathrm{C}$ by consolidated bioprocessing (CBP). They determined $K$. marxianus PT-1 and $S$. cerevisiae $\mathrm{JZ1C}$ were superior in thermotolerance and utilization of inulin-type oligosaccharides in Jerusalem artichoke tubers. It was suggested that these strains have considerable potential in ethanol production from Jerusalem artichoke tubers by high temperature CBP [10]. Kim et al. [13] showed that combining the tuber and the stalk hydrolysate is a useful strategy for whole biomass utilization in effective bioethanol fermentation from Jerusalem artichoke.

In tequila production, fermentation is an important step. Fermentation determines the ethanol productivity and organoleptic properties of the beverage. In a study by López-Alvarez et al. [19], yeast isolated from native residual agave juice from the milling process (must or wort), identified as $K$. marxianus UMPe-1, was demonstrated to be a suitable yeast for agave must fermentation, showing high ethanol productivity and increased volatile compound content compared with a $S$. cerevisiae baker's yeast used in tequila production.

Coffee is one of the most popular beverages of the world and the second largest traded commodity after petroleum $[16,22,24]$. Large amounts of waste are generated in the coffee industry leading to serious environmental issues [2, $22,24]$. With increasing coffee production, it is imperative to apply the techniques of biotechnology in waste management to conserve both ecological and economical resources [22, 25]. Advances in industrial biotechnology offer potential opportunities for economic utilization of coffee industry waste [28]. The main residues of coffee processing are the husks, pulp, mucilage, parchment, and silverskin, comprising $45 \%$ of the coffee fruit [5]. Coffee pulp contains about $13 \mathrm{mg}$ fructans/g and coffee mucilage contains about $35 \mathrm{mg}$ fructans/g [12]. These materials are ideal substrates for microbial processes for the production of value-added products $[23,26]$.

We were interested in evaluating $K$. marxianus mutant strains NRRL Y-50798 (Km7) and NRRL Y-50799 (Km8) [11] for potential use in fermentation of inulin-containing food and plant waste as part of an integrated biorefinery platform. Both of these mutant strains were studied for growth and utilization of chicory inulin (I) in four media, YPD, YPI, YPDI, and $1 \%$ Inulin (see Table 1 for composition). Growth was measured by determining colony forming units $(\mathrm{CFU}) / \mathrm{mL}$. Concentrations of glucose and fructose were measured to determine consumption of glucose or degradation of inulin to fructose. Ethanol production by the mutant strains was also determined in these four media. In addition, inulin extracted from crude coffee processing waste (skin, pulp, and mucilage) was studied as a substrate 
Table 1 Composition of media used in fermentation experiments

\begin{tabular}{lllll}
\hline Component $(\mathrm{g} / \mathrm{L})$ & YPD & YPI & YPDI & $1 \%$ Inulin \\
\hline Yeast & 10 & 10 & 10 & - \\
Peptone & 20 & 20 & 20 & - \\
Glucose & 20 & - & 10 & - \\
Inulin & - & 20 & 10 & 10 \\
\hline
\end{tabular}

for ethanol production. Finally, the level of inulinase activity in these mutant strains was determined.

\section{Materials and methods}

\section{Strains}

K. marxianus mutant strains NRRL Y-50798 (Km7) and NRRL Y-50799 (Km8) were derived from K. marxianus NRRL Y-1109 cultures (USDA, ARS Culture Collection) by UV-C irradiation followed by 5 month growth on glucose at $46{ }^{\circ} \mathrm{C}$ under anaerobic conditions [11]. The strains are optimized for growth at elevated temperature under microaerophilic conditions.

\section{Inulin media composition and preparation}

Four media, YPD, YPI, YPDI, and Inulin, containing different proportions of inulin from chicory (Sigma-Aldrich, St. Louis, MO), sugar (dextrose; Fisher Scientific, Fair Lawn, NJ), yeast $\left(\right.$ Bacto $^{\mathrm{TM}}$ Yeast Extract; Becton, Dickinson and Company, Sparks, MD), and protein (peptone; Bacto ${ }^{\mathrm{TM}}$ Peptone, Becton, Dickinson and Company, Sparks, MD) were prepared using nanopure water. Media were sterilized by autoclaving for $15 \mathrm{~min}$ at $250{ }^{\circ} \mathrm{F}$ and $20 \mathrm{psi}$ (Amsco Renaissance Series 3021 Gravity). The composition of each medium used is shown in Table 1.

\section{Inoculum preparation}

Three colonies of $K$. marxianus mutant strain, either $\mathrm{Km} 7$ or $\mathrm{Km} 8$, used within 15 days of plating on YPD $2 \% \mathrm{w} / \mathrm{v}$ agar Bacto $^{\mathrm{TM}}$ Agar, Becton, Dickinson and Company, Sparks, MD), were inoculated into a $250 \mathrm{~mL}$ flask containing $60 \mathrm{~mL}$ of YPD medium and incubated at $30{ }^{\circ} \mathrm{C}$ with constant shaking at $100 \mathrm{rpm}$ for $48 \mathrm{~h}$. After $48 \mathrm{~h}$ of incubation, the absorbance values at $600 \mathrm{~nm}$ for $\mathrm{Km} 7$ and $\mathrm{Km} 8$ cultures were 1.43 and 1.38, respectively (Hewlett Packard UV/Visible spectrophotometer with ChemStation Software). Therefore, the amounts of inoculum taken to initiate the fermentations were $350 \mu \mathrm{L}$ of the $\mathrm{Km} 7$ liquid culture and $363 \mu \mathrm{L}$ of the $\mathrm{Km} 8$ culture so that the amount of cells initially used was the same for both strains.

\section{Fermentation of inulin mixtures}

Sterile $250 \mathrm{~mL}$ shake flasks containing $60 \mathrm{~mL}$ of each medium were inoculated with a culture of either strain $\mathrm{Km} 7$ or $\mathrm{Km} 8$ grown for $48 \mathrm{~h}$, with the inoculum volume adjusted to contain the same number of cells for each strain. A negative control with no cell culture added was used for each medium to detect changes in concentration of any media components whose consumption or production was being investigated. All cultures were incubated at $30{ }^{\circ} \mathrm{C}$ for $96 \mathrm{~h}$ at $100 \mathrm{rpm}$. At $0,1,2,4,8,24,48,72$ and $96 \mathrm{~h}$, a $2 \mathrm{~mL}$ sample was taken from each flask, $1 \mathrm{~mL}$ for growth determination and $1 \mathrm{~mL}$ for high performance liquid chromatography (HPLC) analysis.

\section{Growth determination}

To determine the growth of the K. marxianus strains tested, $1 \mathrm{~mL}$ samples from each time point were diluted $10^{2}$-fold and $10^{4}$-fold, and spread onto petri dishes containing YPD agar. The dishes were incubated at $30{ }^{\circ} \mathrm{C}$ for $24-48 \mathrm{~h}$, and the CFUs were counted after at least $24 \mathrm{~h}$ of growth.

\section{Determination of glucose, fructose and ethanol concentrations}

At each time point, $1 \mathrm{~mL}$ samples obtained from each fermentation flask were cleared by centrifugation at $14,000 \times g$ for $15 \mathrm{~min}$, and $100 \mu \mathrm{L}$ of supernatant were taken, added to $900 \mu \mathrm{L}$ deionized water, and stored at $-80^{\circ}$ $\mathrm{C}$ until analyzed. Glucose, fructose, and ethanol concentrations were determined at each time point using an HPLC separation system consisting of a solvent delivery system (P2000 pump, Spectra-Physics, San Jose, CA) equipped with an autosampler (717, Waters Chromatography Division, Millipore Corp., Milford, MA) and a computer software based integration system (Chromquest 4.0, SpectraPhysics). An ion moderated partition chromatography column (Aminex HPX 87H with Cation $\mathrm{H}$ micro-guard cartridge; Bio-Rad Laboratories, Inc., Hercules, CA) was used. Samples $(10 \mu \mathrm{L})$ were injected onto a heated column $\left(65^{\circ} \mathrm{C}\right)$, and eluted at a flow rate of $0.6 \mathrm{~mL} / \mathrm{min}$ with $5 \mathrm{mM}$ $\mathrm{H}_{2} \mathrm{SO}_{4}$. Peaks were detected with a refractive index detector (410 differential refractometer, Waters Chromatography Division, Millipore Corp., Milford, MA) and were identified and quantified by comparison to retention times of authentic standards $[4,32]$.

\section{Thin layer chromatography (TLC) determination of glucose, fructose, and inulin}

TLC analyses to determine the presence of fructose, glucose, and inulin in cell-free culture supernatants from 
cultures of strains $\mathrm{Km} 7$ and $\mathrm{Km} 8$ in $1 \%$ inulin were performed at 2, 24, 48, 72 and $96 \mathrm{~h}$ using $20 \times 20 \mathrm{~cm}$ silica gel 60F254 thin layer chromatography plates (EMD Chemicals). Samples were cleared by centrifugation at $10,000 \times g$ for $5 \mathrm{~min}$. A total of $6 \mu \mathrm{L}$ of supernatant was loaded $(2 \mu \mathrm{L}$ aliquots at a time) into separate lanes on the plates. A control of $1 \%$ inulin incubated in the absence of either yeast strain, to evaluate stability of inulin during incubation, and standard solutions of fructose, glucose, and inulin were also applied. A solvent mixture of 1-butanol, 2-propanol, water, and acetic acid (7:5:4:2 v/v/v/v) was employed following the method of Tomita [34]. Spots were visualized by spraying the plate with $4 \mathrm{M} \mathrm{H}_{2} \mathrm{SO}_{4}$ in methanol and heating it at low temperature on a hot plate.

\section{Crude inulin extraction from coffee waste (CW-I)}

Crude inulin (CW-I) was extracted from milled lyophilized coffee processing waste, consisting mainly of skin, pulp, and mucilage from the coffee berry (Cenicafe, Colombia, South America), with hot water $\left(80^{\circ} \mathrm{C}\right)$ for $1 \mathrm{~h}$ using the general method of Mavumengwana [20]. The inulin extract from chicory root obtained using this method contained $80 \%$ inulin and $4 \%$ free fructose [20]. Coffee waste (pulp plus mucilage) has been shown to contain $4.8 \%$ fructans in addition to other sugars and protein that would likely be extracted using this method [12]. $75 \mathrm{~mL}$ of CW-I extract were mixed with $75 \mathrm{~mL}$ of nanopure water and sterilized by autoclave as described above for medium preparation. $20 \mathrm{~mL}$ of the sterile CW-I mixture were transferred into $50 \mathrm{~mL}$ sterile polypropylene blue screw-top test tubes (Fisher Scientific, Fair Lawn, NJ). The CW-I fermentation experiments using mutant strains $\mathrm{Km} 7$ and $\mathrm{Km} 8$ were carried out in the $50 \mathrm{~mL}$ tubes.

\section{Inoculum preparation and fermentation of coffee-waste inulin}

A starter culture was created for both yeast strains ( $\mathrm{Km} 7$ and $\mathrm{Km} 8$ ) for the CW-I fermentation. The starter cultures were grown aerobically for $48 \mathrm{~h}$ at room temperature. For fermentation, $500 \mu \mathrm{L}$ of the $\mathrm{Km} 7$ and $\mathrm{Km} 8$ starter cultures were used to inoculate $20 \mathrm{~mL}$ of CW-I in each of two $50 \mathrm{~mL}$ fermentation tubes. These were then grown aerobically at $30^{\circ} \mathrm{C}$ with shaking at $150 \mathrm{rpm}$ in a New Brunswick Scientific Co Inc. Series 25 Incubator Shaker. During the experiment, a $2 \mathrm{~mL}$ sample of each of the CW-I fermentations was taken at $0,6,12,24,30,48,72 \mathrm{~h}$. One $\mathrm{mL}$ was frozen at $-80{ }^{\circ} \mathrm{C}$ to use for $\mathrm{GC}$ determination of ethanol production, while the other $1 \mathrm{~mL}$ was analyzed for cell growth. To determine growth, $10 \mu \mathrm{L}$ of the fermentation broths were diluted $10^{2}$-fold and $10^{4}$-fold, spread with a sterile cell spreader onto petri dishes containing YPD agar, and incubated for $24-48 \mathrm{~h}$ at $30{ }^{\circ} \mathrm{C}$ before CFUs were determined.

\section{Detection of ethanol by gas chromatography}

A Thermo Scientific Focus GC-FID with an auto-sampler (AS3000) was used for detection of ethanol production. A set of ethanol standards were prepared to determine the concentration of ethanol produced during the fermentation. A $5 \%(\mathrm{v} / \mathrm{v}) n$-propanol internal standard was added to each of the standards and samples to determine reproducibility of instrument response. Stored frozen samples were thawed and the cells pelleted by centrifugation. Then $500 \mu \mathrm{L}$ of the supernatant were transferred to a $\mathrm{GC}$ vial and $450 \mu \mathrm{L}$ of nanopure water and the internal standard $(50 \mu \mathrm{L})$ were added for a final volume of $1 \mathrm{~mL}$. Duplicate injection volumes of $0.7 \mu \mathrm{L}$ were used; the inlet and detector were set to $250{ }^{\circ} \mathrm{C}$. The carrier gases, helium $(175 \mathrm{kPa})$, compressed air $(220 \mathrm{kPa})$, and nitrogen $(500 \mathrm{kPa})$, were at a constant flow of $1.2 \mathrm{~mL} / \mathrm{min}$. Each GC separation was run for $2.5 \mathrm{~min}$ at $75{ }^{\circ} \mathrm{C}$.

\section{Zymogram assay}

The activity of secreted inulinase from mutant strains $\mathrm{Km} 7$ and $\mathrm{Km} 8$ was evaluated using a modified zymogram procedure [8]. An agarose $(1 \% \mathrm{w} / \mathrm{v})$ suspension with chicory inulin $(0.1 \%$ w/v; Sigma-Aldrich, St. Louis, MO) in nanopure water was heated in a microwave and poured into a Bio-Rad Sub-Cell horizontal tray $(10 \times 15 \mathrm{~cm})$. After cooling to room temperature, the gel was cut into pieces $50-55 \mathrm{~mm}$ on each side, and each piece was placed into a $100 \mathrm{~mm}$ petri dish. A cell suspension of each of the strains was prepared by placing several colonies obtained from YPD agar plates into $1 \mathrm{~mL}$ of sterile nanopure water and mixing gently. The suspension was applied to the inulin-containing gels using a $10 \mu \mathrm{L}$ inoculation loop. Negative controls were inulin gel pieces with no suspension added. The gels were incubated at $30{ }^{\circ} \mathrm{C}$ for 5 days and observed for growth. A Sigma-Aldrich Periodic AcidSchiff (PAS) staining kit (Sigma-Aldrich, St. Louis, MO) was used according to instructions to stain the gels. The periodic acid solution was added to the petri dish and swirled for 30-60 s to allow complete coverage of the gel. Excess solution was decanted and the Schiff reagent was added and swirled in the same manner. When treated with periodic acid, glycols are oxidized to aldehydes. After reaction with Schiff's reagent (a mixture of pararosaniline and sodium metabisulfite), a pararosaniline adduct is released that stains the glycol-containing cellular elements pink to red or violet. The PAS system produces a pink color with inulin (Sigma-Aldrich). Absence of pink color in the inulin-containing gel indicates degradation of 
the inulin. The gel was observed for presence or absence of a pink color.

\section{Quantitation of inulinase activity}

Quantitative data for inulinase activity of mutant strains $\mathrm{Km} 7$ and $\mathrm{Km} 8$ were obtained by HPLC analysis of fructose formed using cultures of the mutant strains compared to standard solutions of inulinase (endohydrolase from Aspergillis niger; EC Number 3.2.1.7; 240 IU/mL; SigmaAldrich, St. Louis, MO) with $0.2 \%$ chicory inulin as the substrate. The activity of inulinase from A. niger is similar to that from $K$. marxianus, for example, using inulin from dahlia tuber extract as substrate, inulinase activity for $A$. niger was $2-4 \mathrm{U} / \mathrm{mL}$ and for $K$. marxianus was $1.5 \mathrm{U} / \mathrm{mL}$ [31]. Four standard inulinase solutions were each prepared in triplicate by adding $10 \mu \mathrm{L}$ of undiluted, 10-, 100-, and 1000 -fold dilutions of the standard inulinase solution to $40 \mu \mathrm{L}$ of $50 \mathrm{mM}$ sodium phosphate buffer ( $\mathrm{pH} 7$ ) and adding the solution to $850 \mu \mathrm{L}$ of sterile water in a microfuge tube, followed by addition of $100 \mu \mathrm{L}$ of inulin $(20 \mathrm{mg} / \mathrm{mL})$ to the tube [21 modified]. Suspensions (no dilution and 10 -fold dilution) of 2 day $30^{\circ} \mathrm{C}$ cultures of strains $\mathrm{Km} 7$ and $\mathrm{Km} 8$ adjusted to $\mathrm{OD}=2$ at $600 \mathrm{~nm}$ were prepared similarly. The tubes were capped and incubated at $30{ }^{\circ} \mathrm{C}$ for 2,4 , and $6 \mathrm{~h}$. At each time point, the tubes were removed from the incubator and placed in a water bath at $90{ }^{\circ} \mathrm{C}$ for $10 \mathrm{~min}$ to inactivate the enzyme (inulinase denatures at $\left.77^{\circ} \mathrm{C}[30]\right)$. The amount of fructose formed in the solutions was measured using HPLC. The inulinase activity versus the amount of fructose released (area under fructose HPLC peak) was plotted for the standards (data not shown). The inulinase activities in $\mathrm{Km} 7$ and $\mathrm{Km} 8$ were determined from the standard plots using the area under the fructose peaks in the $\mathrm{Km} 7$ and $\mathrm{Km} 8$ reactions.

\section{Results}

\section{Growth levels}

Growth levels (CFU/mL) as a function of incubation time for mutant strains $\mathrm{Km} 7$ and $\mathrm{Km} 8$ with 4 different media, YPD, YPI, YPDI, and $1 \%$ chicory inulin, are shown in Figs. 1-3a-d, respectively. For mutant strain $\mathrm{Km} 7$, the most favorable media for growth were YPI and YPDI, in
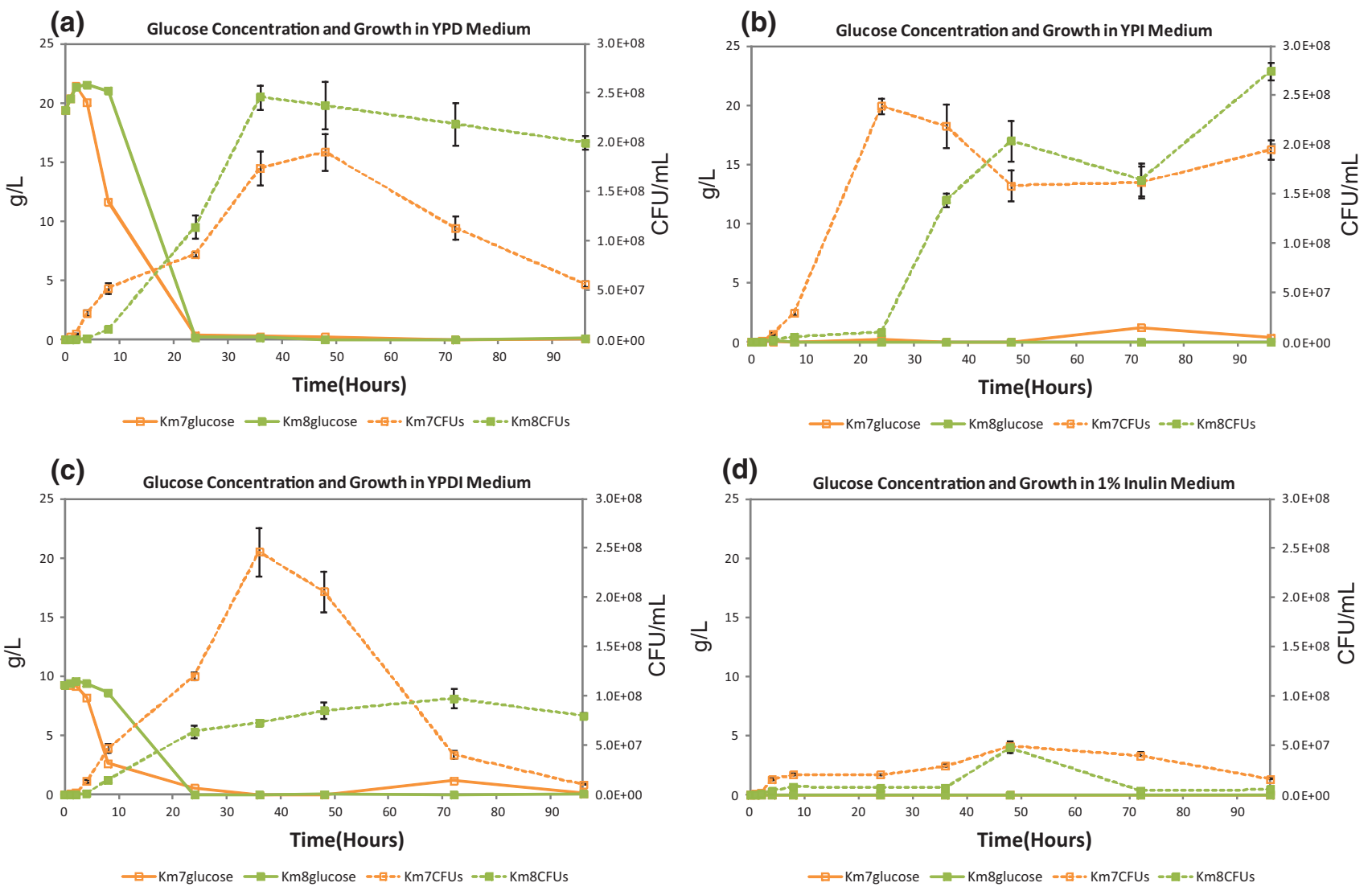

Fig. 1 Glucose concentrations and cell growth as a function of incubation time with mutant strains Km7 and Km8 using 4 different media: a YPD, b YPI, c YPDI, and d $1 \%$ inulin 
both of which $\mathrm{Km} 7$ showed maximum growth of about $2.5 \times 10^{8} \mathrm{CFU} / \mathrm{mL}$ at 24 and $36 \mathrm{~h}$, respectively (Fig. $1 \mathrm{~b}$, c). YPI medium (Fig. 1b) appeared to sustain growth over a longer time relative to YPD and YPDI media. The maximum growth of $\mathrm{Km} 7$ in YPD medium was $1.9 \times 10^{8} \mathrm{CFU} /$ $\mathrm{mL}$ at $48 \mathrm{~h}$ (Fig. 1a). Growth of $\mathrm{Km} 7$ in $1 \%$ (w/v) chicory inulin medium reached a maximum of $5.0 \times 10^{7} \mathrm{CFU} /$ $\mathrm{mL}$ at $48 \mathrm{~h}$, then decreased to a sustained level of about $2.0 \times 10^{7} \mathrm{CFU} / \mathrm{mL}$ up to $96 \mathrm{~h}$ (Fig. $1 \mathrm{~d}$ ).

Mutant strain $\mathrm{Km} 8$ demonstrated greatest growth in YPD and YPI media, with the maximum of $2.5 \times 10^{8}$ $\mathrm{CFU} / \mathrm{mL}$ occurring at $36 \mathrm{~h}$ in YPD medium (Fig. 1a) and a maximum of $2.7 \times 10^{8} \mathrm{CFU} / \mathrm{mL}$ occurring at $96 \mathrm{~h}$ in YPI medium (Fig. 1b). In YPI medium, in contrast to $\mathrm{Km} 7$ where the growth maximum was at $24 \mathrm{~h}$ with a slow decrease to about $2.0 \times 10^{8} \mathrm{CFU} / \mathrm{mL}$ at $96 \mathrm{~h}, \mathrm{Km} 8$ showed a lag time of $24 \mathrm{~h}$ before growth started, with an initial growth peak of $2.0 \times 10^{8} \mathrm{CFU} / \mathrm{mL}$ observed at $48 \mathrm{~h}$, a decrease to $1.6 \times 10^{8}$ $\mathrm{CFU} / \mathrm{mL}$ at $72 \mathrm{~h}$, and an increase to $2.7 \times 10^{8} \mathrm{CFU} / \mathrm{mL}$ (and still rising) at $96 \mathrm{~h}$ (Fig. 1b). In YPDI medium, maximum growth of Km8 was $1.0 \times 10^{8} \mathrm{CFU} / \mathrm{mL}$ at $72 \mathrm{~h}$ (Fig. 1c) about $40 \%$ that of $\mathrm{Km} 7$ in YPDI at $36 \mathrm{~h}$ (or of $\mathrm{Km} 8$ in YPD at $36 \mathrm{~h}$ ). In $1 \%$ inulin medium, growth of $\mathrm{Km} 8$ reached a maximum of $5.0 \times 10^{7} \mathrm{CFU} / \mathrm{mL}$ at $48 \mathrm{~h}$ dropping to an undetectable level at the remaining time points (Fig. 1d). The growth results are summarized in Table 2.

\section{Glucose, fructose, and ethanol concentrations determined by HPLC}

Glucose concentrations $(\mathrm{g} / \mathrm{L})$ as a function of incubation time using mutant strains $\mathrm{Km} 7$ and $\mathrm{Km} 8$ with 4 different media, YPD, YPI, YPDI, and $1 \%$ chicory inulin, are shown in Fig. 1a-d, respectively. Growth levels (CFU/mL) as a function of time are also presented. In YPD and YPDI media for both the $\mathrm{Km} 7$ and $\mathrm{Km} 8$ mutant strains, glucose is essentially completely utilized by $24 \mathrm{~h}$, with maximum growth occurring at approximately $36 \mathrm{~h}$ for $\mathrm{Km} 7$ in both media and for Km8 in YPD (Fig. 1a, c). However, Km8 in YPDI, although nearly all glucose was consumed at $24 \mathrm{~h}$ (concentration was not completely to baseline until $36 \mathrm{~h}$; Fig. 1c), exhibited only a gradual increase to a relatively low maximum growth at $72 \mathrm{~h}$ (40\% of that in YPD). In YPI and $1 \%$ inulin media (Fig. 1b, d), glucose is essentially not detected for either strain except for a small peak $(0.5 \mathrm{~g} / \mathrm{L})$ at $72 \mathrm{~h}$ for $\mathrm{Km} 7 \mathrm{in} \mathrm{YPI}$. Both $\mathrm{Km} 7$ and $\mathrm{Km} 8$ strains grow well in YPI medium, but, although maximum growth levels are similar for both strains, for $\mathrm{Km} 7$ the maximum occurs at $24 \mathrm{~h}$, while for $\mathrm{Km} 8$ it occurs at $48 \mathrm{~h}$ (Fig. 1b). In $1 \%$ inulin medium (Fig. 1d), no glucose is detected (only one line is shown), and the maximum growth at $48 \mathrm{~h}$ of $\mathrm{Km} 7$ was $20 \%$ and of $\mathrm{Km} 8$ was $12 \%$ of that for these strains in YPI.
Fructose concentrations $(\mathrm{g} / \mathrm{L})$ and cell growth (CFU/ $\mathrm{mL}$ ) as a function of incubation time using mutant strains $\mathrm{Km} 7$ and $\mathrm{Km} 8$ with the 4 different media, YPD, YPI, YPDI, and $1 \%$ chicory inulin, are presented in Fig. 2a-d, respectively. Note that the scale on the left y-axis denoting sugar concentration is different on Figs. 1 and 2, while the scale on the right $y$-axis representing cell growth is the same on all figures. No fructose is detected in YPD medium at any time point (only one line is shown) with either $\mathrm{Km} 7$ or $\mathrm{Km} 8$ (Fig. 2a). In YPDI medium, fructose is present for both strains, with $\mathrm{Km} 7$ reaching a maximum of about $0.8 \mathrm{~g} / \mathrm{L}$ at 8-24 h, dropping to an undetectable level at $48 \mathrm{~h}$, then returning to about $0.8 \mathrm{~g} / \mathrm{L}$ at $72 \mathrm{~h}$, and with $\mathrm{Km} 8$ starting at $0.7 \mathrm{~g} / \mathrm{L}$ at $2 \mathrm{~h}$ and decreasing to a negligible level $(<0.1 \mathrm{~g} / \mathrm{L})$ by $24-96 \mathrm{~h}$ (Fig. 2c). In YPI medium both strains show somewhat similar fructose patterns to those they displayed in YPDI, with fructose concentration for $\mathrm{Km} 7$ reaching a maximum of about $1.4 \mathrm{~g} / \mathrm{L}$ at $8 \mathrm{~h}$, dropping to a negligible level at $48 \mathrm{~h}$, returning to about $0.9 \mathrm{~g} / \mathrm{L}$ at $72 \mathrm{~h}$, then dropping to negligible at $96 \mathrm{~h}$, and for $\mathrm{Km} 8$ reaching a maximum of $0.4 \mathrm{~g} / \mathrm{L}$ at $4 \mathrm{~h}$ and leveling off to about $0.3 \mathrm{~g} / \mathrm{L}$ by $24 \mathrm{~h}$ and continuing at that level to $96 \mathrm{~h}$ (Fig. 2b). In the $1 \%$ inulin medium, the fructose concentration in the $\mathrm{Km} 7$ culture increases steadily from $<0.1 \mathrm{~g} / \mathrm{L}$ initially to $2.4 \mathrm{~g} / \mathrm{L}$ at $96 \mathrm{~h}$, while the fructose concentration in the $\mathrm{Km} 8$ culture is negligible $(<0.1 \mathrm{~g} / \mathrm{L})$ from 0 to $96 \mathrm{~h}$ (Fig. $2 \mathrm{~d})$.

Ethanol production $(\mathrm{g} / \mathrm{L})$ and cell growth $(\mathrm{CFU} / \mathrm{mL})$ as a function of incubation time using mutant strains $\mathrm{Km} 7$ and $\mathrm{Km} 8$ with four different media, YPD, YPI, YPDI, and $1 \%$ inulin, are shown in Fig. 3a-d, respectively. In YPD medium (Fig. 3a), ethanol production was similar for the two strains (maximum of about $8.0 \mathrm{~g} / \mathrm{L}$ at approximately $24 \mathrm{~h}$ ), although $\mathrm{Km} 8$ achieved slightly higher maximum growth $\left(2.5 \times 10^{8}\right.$ $\mathrm{CFU} / \mathrm{mL}$ at $36 \mathrm{~h})$ than $\mathrm{Km} 7\left(1.9 \times 10^{8} \mathrm{CFU} / \mathrm{mL}\right.$ at $\left.48 \mathrm{~h}\right)$. In YPDI medium (Fig. 3c), ethanol production for $\mathrm{Km} 7$ followed the same pattern as in YPD medium; however, ethanol production for Km8 in YPDI medium was much lower, with a maximum of about $4 \mathrm{~g} / \mathrm{L}$ at $24 \mathrm{~h}$, half that of $\mathrm{Km} 8$ in YPD medium, correlating with the reduced growth of $\mathrm{Km} 8$ in YPDI medium (maximum $1.0 \times 10^{8} \mathrm{CFU} / \mathrm{mL}$ at $72 \mathrm{~h}$ ), about $40 \%$ that of Km8 in YPD medium. In YPI medium (Fig. 3b), maximum growth with $\mathrm{Km} 8$ was similar to that with $\mathrm{Km} 7$, although the maximum for $\mathrm{Km} 8$ was at $96 \mathrm{~h}$ while that for $\mathrm{Km} 7$ was at $24 \mathrm{~h}$, earlier than in YPD and YPDI media. However, Km8 produced a negligible amount of ethanol, while $\mathrm{Km} 7$ produced the same maximum amount of ethanol as in YPD and YPDI media (about $8 \mathrm{~g} / \mathrm{L}$ ) but, notably, the maximum appeared about $12 \mathrm{~h}$ earlier in YPI medium coinciding with maximum growth. When grown in $1 \%$ inulin medium, neither strain produced ethanol (only one line is shown); however, $\mathrm{Km} 7$ exhibited sustained low level growth ( 2 to $5 \times 10^{7} \mathrm{CFU} / \mathrm{mL}$, maximum at $48 \mathrm{~h}$ ) while $\mathrm{Km} 8$ produced a small growth peak reaching $5.0 \times 10^{7} \mathrm{CFU} / \mathrm{mL}$ 


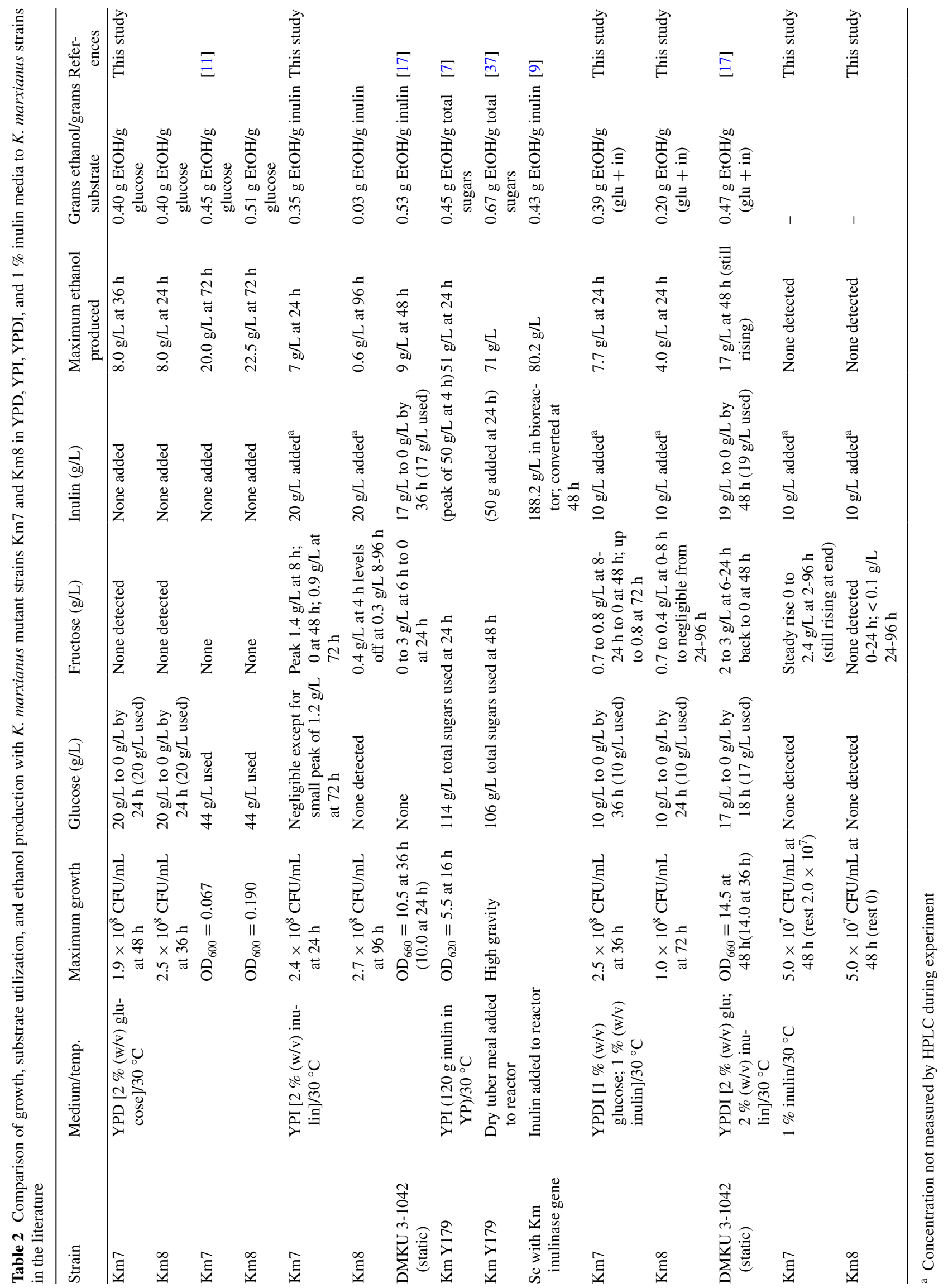



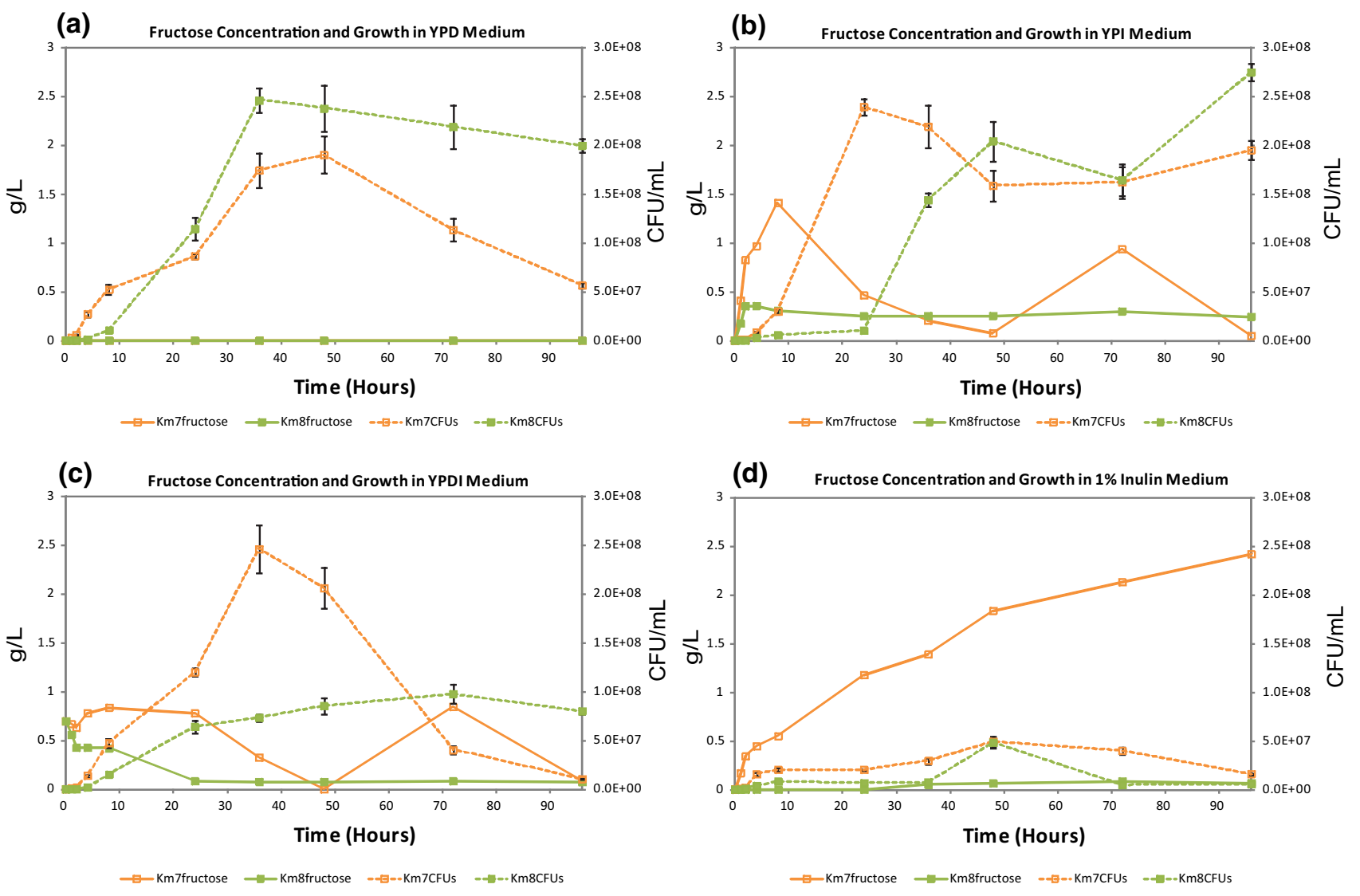

Fig. 2 Fructose concentrations and cell growth as a function of incubation time with mutant strains $\mathrm{Km} 7$ and $\mathrm{Km} 8$ using 4 different media: a YPD, b YPI, c YPDI, and $\mathbf{d} 1 \%$ inulin

above baseline at $48 \mathrm{~h}$ (Fig. 3d). The glucose, fructose, and ethanol results are summarized in Table 2 .

\section{Thin layer chromatography results}

Thin layer chromatography results of samples taken at 2, 24, 48,72 , and $96 \mathrm{~h}$ during the incubation of mutant strains $\mathrm{Km} 7$ and $\mathrm{Km} 8$ in $1 \%$ inulin medium are presented in Fig. 4. The chromatogram for $\mathrm{Km} 7$ in $1 \%$ inulin indicated production of fructose with a decrease in the amount of inulin. The chromatogram for $\mathrm{Km} 8$ showed the presence of inulin with no significant degradation to fructose. The chromatogram for a control sample of $1 \%$ inulin medium incubated for $96 \mathrm{~h}$ without added yeast is also provided in Fig. 4, indicating no degradation of inulin occurred in the absence of the yeast strains.

\section{Fermentation of crude inulin extract from coffee waste (CW-I)}

Fermentation of crude inulin from coffee processing waste by mutant strains $\mathrm{Km} 7$ or $\mathrm{Km} 8$ is shown in Fig. $5 \mathrm{a}-\mathrm{b}$, respectively. The growth $(\mathrm{CFU} / \mathrm{mL})$ and the amount of ethanol $(\mathrm{g} / \mathrm{L})$ detected are shown as a function of time. Mutant strain $\mathrm{Km} 7$ reached a maximum growth of $8.0 \times 10^{7} \mathrm{CFU} /$ $\mathrm{mL}$ at $24 \mathrm{~h}$, while mutant strain $\mathrm{Km} 8$ reached a maximum growth of $6.0 \times 10^{7} \mathrm{CFU} / \mathrm{mL}$ at $30 \mathrm{~h}$. For both strains, maximum growth was correlated with maximum production of ethanol. For $\mathrm{Km} 7$ maximum ethanol production was $10 \mathrm{~g} / \mathrm{L}$ and for $\mathrm{Km} 8$ it was $9 \mathrm{~g} / \mathrm{L}$.

\section{Demonstration of inulinase activity}

Zymogram analysis was used to demonstrate inulinase activity by the mutant yeast strains. An aqueous suspension of $\mathrm{Km} 7$ or $\mathrm{Km} 8$ colonies grown on YPD agar was applied to an agarose gel containing $0.1 \%(\mathrm{w} / \mathrm{v})$ inulin and incubated for 5 days at $30{ }^{\circ} \mathrm{C}$. When periodic acid solution and Schiff's reagent were added to the negative control inulin gel and the color allowed to develop, the entire surface of the gel was an even pink color. On the gel containing mutant strain $\mathrm{Km} 7$, which occupied a circular region of growth about $2.5 \mathrm{~cm}$ in diameter, a colorless ring (halo) about $5 \mathrm{~mm}$ wide evenly surrounding the entire circumference of the region of cell growth was observed, while the gel beyond the colorless ring was pink. The area of cell growth was stained purple. For mutant strain Km8 the colorless ring 

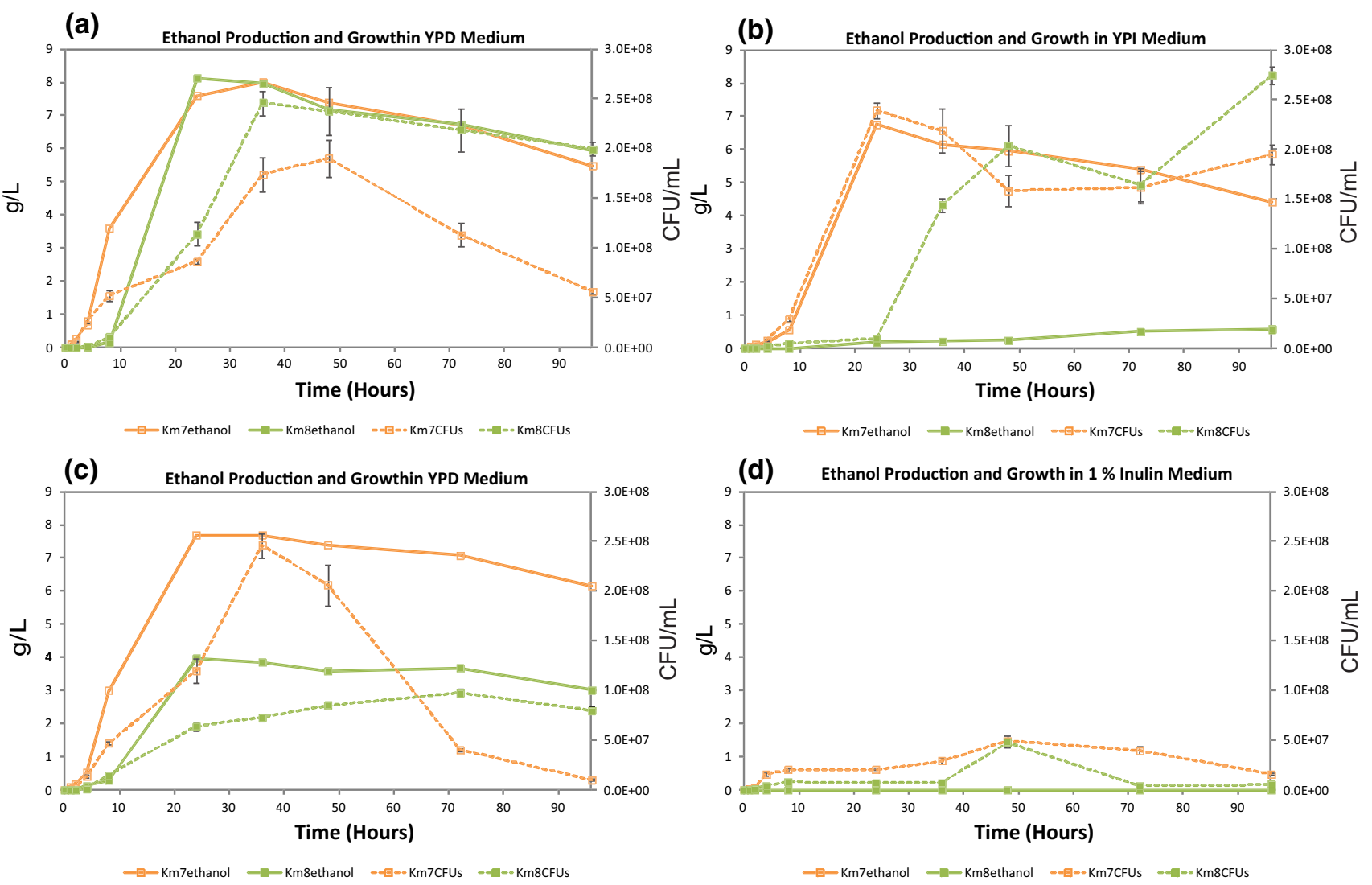

Fig. 3 Ethanol production and cell growth as a function of incubation time with mutant strains Km7 and Km8 using 4 different media: a YPD, b YPI, c YPDI, and $\mathbf{d} 1 \%$ inulin

Fig. 4 Thin layer chromatography determination of glucose (dextrose), fructose, and inulin; panel 1: standard glucose, fructose, and inulin solutions; panels 2 and 3: mutant strains $\mathrm{Km} 7$ and $\mathrm{Km} 8$ incubated in $1 \%$ inulin; panel $4: 1 \%$ inulin incubated without either strain added

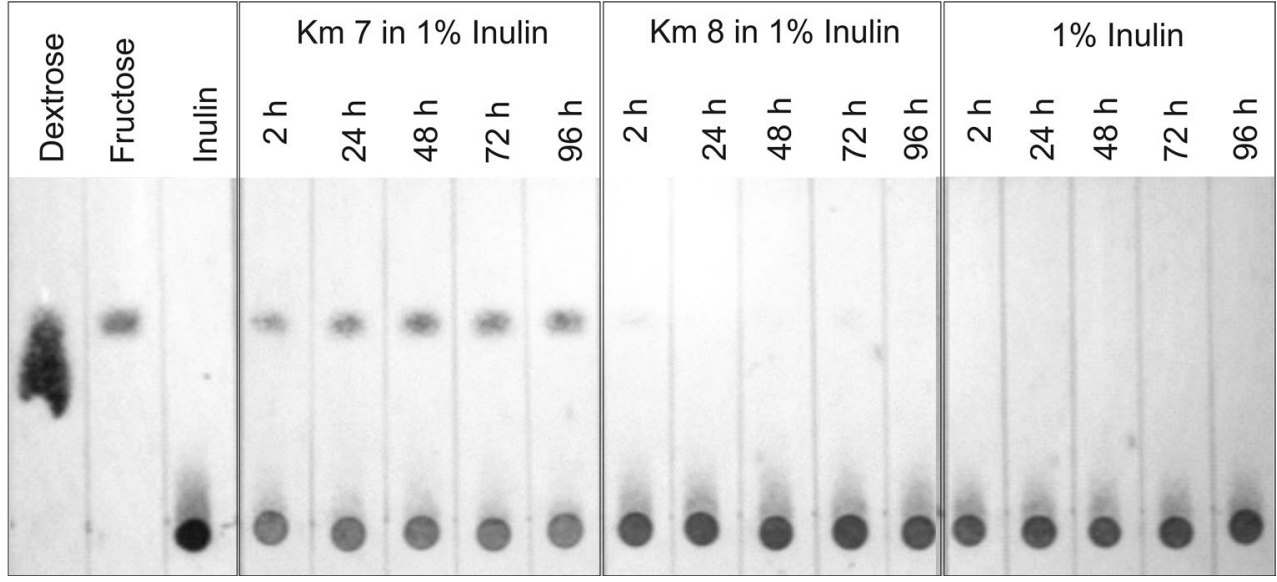

was about one-third the width of that for mutant strain $\mathrm{Km} 7$ (data not shown). The results for $\mathrm{Km} 7$ are depicted in Figure A1 in the Supplementary Electronic Information.

\section{Quantitation of inulinase activity}

Results quantitating inulinase activity of mutant strains $\mathrm{Km} 7$ and $\mathrm{Km} 8$, using HPLC to measure the amount of fructose (area under peak) produced from $0.2 \%$ inulin at 2,4 , and $6 \mathrm{~h}$ by these strains compared to a standard inulinase solution, are provided in Fig. 6. Extracellular inulinase activity for undiluted $\mathrm{Km} 7$ strain was $0.13 \mathrm{IU} /$ $\mathrm{mL}$ at $2 \mathrm{~h}$, rose to $1.4 \mathrm{IU} / \mathrm{mL}$ at $4 \mathrm{~h}$ and continued to rise to $3.7 \mathrm{IU} / \mathrm{mL}$ at $6 \mathrm{~h}$. Extracellular inulinase activity at $2 \mathrm{~h}$ for undiluted $\mathrm{Km} 8,1.83 \mathrm{IU} / \mathrm{mL}$, was higher than that for $\mathrm{Km} 7$. The level for $\mathrm{Km} 8$ increased to a 

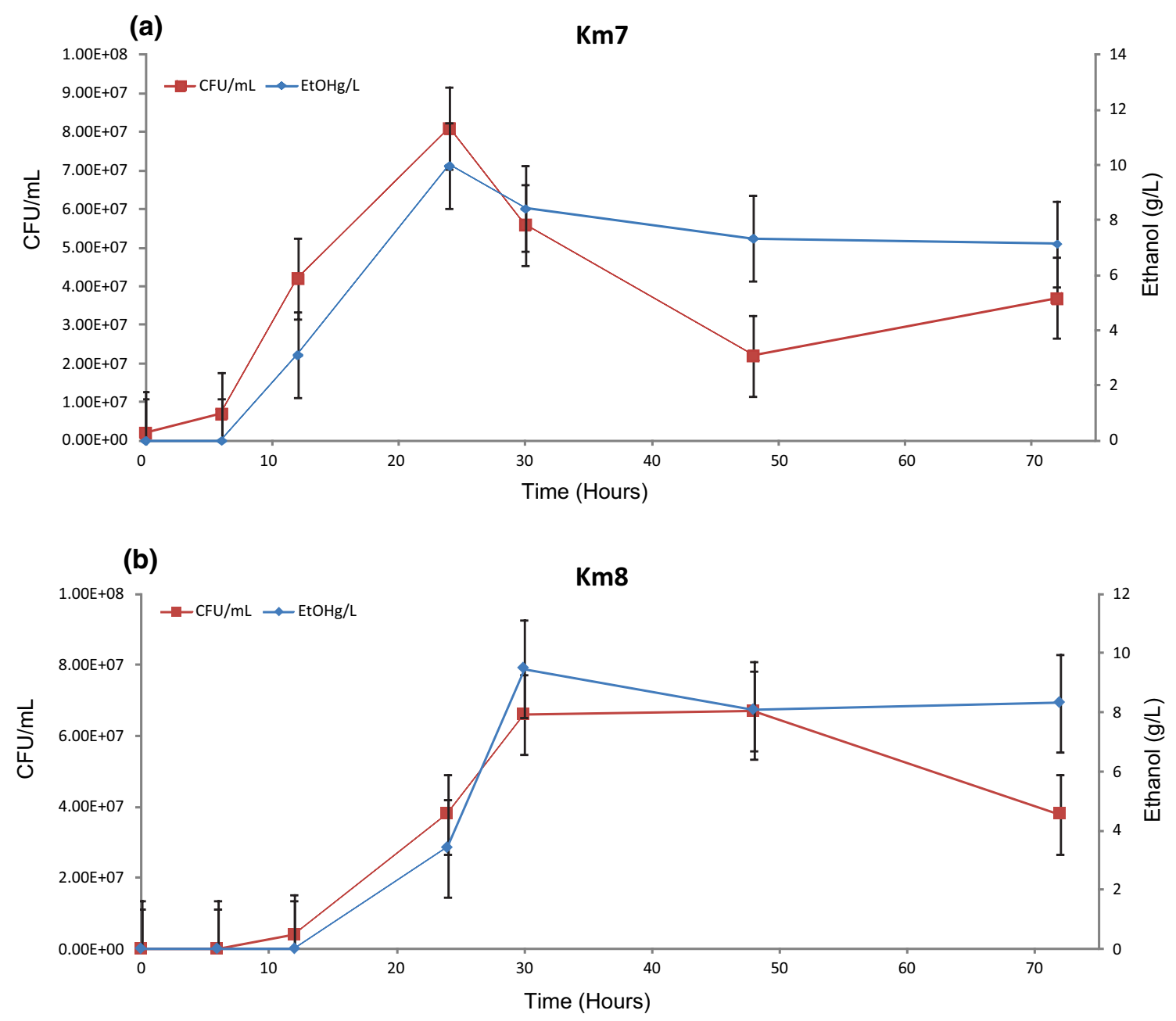

Fig. 5 Ethanol production $(\mathrm{g} / \mathrm{L})$ and cell growth $(\mathrm{CFU} / \mathrm{mL})$ for mutant strain $\mathrm{Km} 7 \mathbf{a}$ or $\mathrm{Km} 8 \mathbf{b}$ in medium with crude inulin extracted from coffee processing waste

maximum of $4.4 \mathrm{IU} / \mathrm{mL}$ at $4 \mathrm{~h}$ and then decreased to $3.7 \mathrm{IU} / \mathrm{mL}$ at $6 \mathrm{~h} . \mathrm{Km} 7$ at its maximum at $6 \mathrm{~h}$ was at the same level as $\mathrm{Km} 8$ at $6 \mathrm{~h}$, but its activity appeared to be continuing to increase unlike that of $\mathrm{Km} 8$, which was decreasing at that point. Extracellular inulinase activity of a 10 -fold dilution of $\mathrm{Km} 7$ followed a similar pattern to that of $\mathrm{Km} 8$, reaching a similar maximum at $4 \mathrm{~h}, 0.60 \mathrm{IU} / \mathrm{mL}$ for $\mathrm{Km} 7$ and $0.69 \mathrm{IU} / \mathrm{mL}$ for $\mathrm{Km} 8$. Both mutant strains gave secreted inulinase activity levels comparable to those for $K$. marxianus reported in the literature on various inulin substrates. Rawat et al. [31] obtained inulinase activity values at $72 \mathrm{~h}$ for $K$. marxianus MTCC 3995 of $0.41 \mathrm{U} / \mathrm{mL}$ on asparagus root extract and of $1.49 \mathrm{U} / \mathrm{mL}$ on dahlia tuber extract. Yuan and co-workers [37] determined values of 3-4 U/mL for inulinase activity of $K$. marxianus $\mathrm{Y} 179$ between 12 and $48 \mathrm{~h}$ in fermentation experiments using Jerusalem artichoke tuber meal.

\section{Discussion}

Both $K$. marxianus mutant strains used in this study grew well in YPD medium utilizing all available glucose by $24 \mathrm{~h}$ and producing ethanol in amounts comparable to the amounts previously obtained with these strains [11]. Maximum growth in YPD was slightly higher and earlier for $\mathrm{Km} 8$ than $\mathrm{Km} 7$. Maximum ethanol production correlated with the depletion of glucose at $24 \mathrm{~h}$ for $\mathrm{Km} 7$ and $\mathrm{Km} 8$. Ethanol yield was the same for both strains $(0.40 \mathrm{~g}$ ethanol/g glucose). In YPI medium, both strains grew well, but the Km7 cells reached maximum growth sooner than $\mathrm{Km} 8$, possibly the result of more rapid production of fructose, with the maximum growth peak for $\mathrm{Km} 7$ at $24 \mathrm{~h}$ compared to $96 \mathrm{~h}$ for $\mathrm{Km} 8$ suggesting $\mathrm{Km} 7$ was able to hydrolyze inulin or induce inulinase more readily than $\mathrm{Km} 8$. The maximum concentration of fructose in YPI occurred at $8 \mathrm{~h}$ for $\mathrm{Km} 7$, but the level of fructose for $\mathrm{Km} 8$ never rose as 


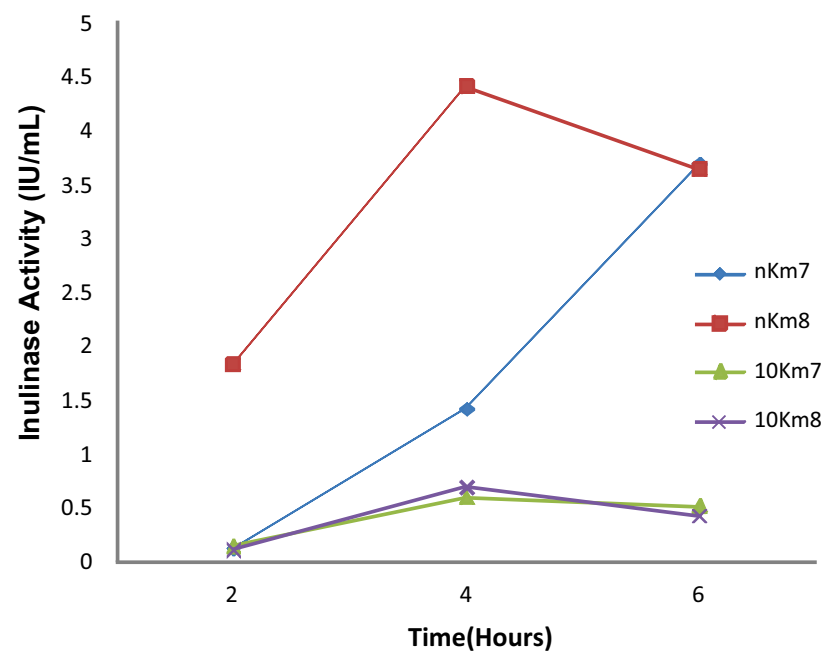

Fig. 6 Inulinase activity (International Units (IU)/mL) of mutant strains $\mathrm{Km} 7$ and $\mathrm{Km} 8$, using HPLC to measure the amount of fructose (area under peak) produced from incubation of cell cultures at $30{ }^{\circ} \mathrm{C}$ with $0.2 \%$ inulin solution at 2,4 , and $6 \mathrm{~h}$ by these strains compared to a standard inulinase solution. Key: $\mathrm{n} \mathrm{Km} 7=$ undiluted $\mathrm{Km} 7$ culture; $\mathrm{n} \mathrm{Km} 8=$ undiluted $\mathrm{Km} 8$ culture; $10 \mathrm{Km} 7=10$-fold dilution of $\mathrm{Km} 7$ culture; $10 \mathrm{Km} 8$ is 10 -fold dilution of $\mathrm{Km} 8$ culture

high and remained much lower throughout the $96 \mathrm{~h}$. For $\mathrm{Km} 7$ in YPI, the rise in $\mathrm{CFU} / \mathrm{mL}$ at $72 \mathrm{~h}$ following the drop in growth after maximum growth corresponds to the second fructose peak at $72 \mathrm{~h}$, which is possibly related to inulinase induction. The release of fructose may explain the increase in $\mathrm{CFU} / \mathrm{mL}$ at that time. Most reports in the literature show complex behavior of inulinases on inulin substrates for a variety of reasons [20], but a similar drop after maximum growth followed by a rise in cell growth has been reported $[7,20]$. However, the same explanation does not apply to the similar rise in cell growth for $\mathrm{Km} 8$. Although $\mathrm{Km} 7$ and $\mathrm{Km} 8$ showed the same inulinase activity level at $6 \mathrm{~h}, \mathrm{Km} 8$ in YPI at $72 \mathrm{~h}$ did not release fructose at the same time or in the same amount as $\mathrm{Km} 7$, so the reason for the rise in growth for $\mathrm{Km} 8$ is not clear. It may possibly be linked to a difference between the two strains in the induction of inulinases, but further assessment is needed. It was of interest to note that with the $\mathrm{Km} 7$ cells, glucose was detectable at $72 \mathrm{~h}$ (although glucose was not added to the medium). We speculate that enzymes in $\mathrm{Km} 7$ release the small amount of glucose present at the inulin polymer termini linked through a sucrose bond. In YPDI medium with $\mathrm{Km} 8$, the amount of glucose was reduced to undetectable levels by $24 \mathrm{~h}$ of incubation similar to Km8 in YPD medium, while with $\mathrm{Km} 7$ in YPDI medium, glucose was not completely depleted until $36 \mathrm{~h}$ (although most was consumed by $24 \mathrm{~h}$ ) in contrast to $\mathrm{Km} 7$ in YPD medium. For both strains the fructose concentration trends were similar in YPI and YPDI media. The maximum growth of $\mathrm{Km} 7$ in YPDI medium was slightly higher than that of Km7 in YPI medium; however, although $\mathrm{Km} 8$ in YPDI consumed nearly all available glucose by $24 \mathrm{~h}$, this strain exhibited only a gradual increase to a relatively low maximum growth at $72 \mathrm{~h}$ (about $40 \%$ that of $\mathrm{Km} 8$ in YPI), indicating glucose repression of inulin utilization as reported in the literature [6, 17]. In YPDI medium, the maximum growth rate of $\mathrm{Km} 8$ was about $40 \%$ that of $\mathrm{Km} 7$ in YPDI, suggesting this repression affects $\mathrm{Km} 8$ more than $\mathrm{Km} 7$, although growth decreased for $\mathrm{Km} 7$ in YPDI at $72 \mathrm{~h}$ compared to $\mathrm{Km} 7$ and $\mathrm{Km} 8$ in YPI medium. Gao et al. [6] showed that glucose repressed inulinase production at $30{ }^{\circ} \mathrm{C}$, while inulin induced inulinase production. In $1 \%$ inulin medium, no glucose is detected and the maximum growth at $48 \mathrm{~h}$ of $\mathrm{Km} 7$ was $20 \%$ and of $\mathrm{Km} 8$ was $12 \%$ that of these strains in YPI medium. No ethanol was produced by either strain in the $1 \%$ chicory inulin medium. In YPI and YPDI media, Km7 produced more ethanol than $\mathrm{Km} 8$, whereas in YPD medium, the production was comparable for the two strains. A comparison of growth, substrate utilization, and ethanol production with K. marxianus mutant strains $\mathrm{Km} 7$ and $\mathrm{Km} 8$ in YPD, YPI, YPDI, and $1 \%$ inulin media to K. marxianus strains in the literature is provided in Table 2.

When crude inulin extracted from coffee processing waste was used as substrate, the growth of $\mathrm{Km} 7$ cells peaked at about $24 \mathrm{~h}$, whereas the growth of $\mathrm{Km} 8$ peaked at about $30 \mathrm{~h}$. In both cases, ethanol production was highest at maximum growth. The amount of inulin present in coffee waste is not well documented and depends on the coffee species, type of processing, and method of extraction. Muthuselvi et al. [26] reported that in spent coffee grounds, a byproduct of the coffee brewing operation that represents $10 \%$ of the total weight of the fresh grain [35], the amount of inulin extracted under normal conditions using hot water at $90{ }^{\circ} \mathrm{C}$ for $100 \mathrm{~min}$ was $40 \mu \mathrm{g} / \mathrm{mL}(0.004 \%)$. In a study using a mixture of coffee pulp and mucilage to simulate coffee waste, the pulp was found to contain $1.3 \%$ fructans and the mucilage was found to contain $3.5 \%$ fructans [12]. The growth and production of ethanol in the crude inulin extract by mutant strains $\mathrm{Km} 7$ and $\mathrm{Km} 8$ is probably attributable to other molecules in the extract such as proteins and sugars in addition to fructans.

In the zymogram experiments, after staining with PAS, a colorless halo was observed surrounding the region of cell growth of the mutant strains in the inulin-containing gel indicating the absence of inulin, and demonstrating degradation of the inulin in the gel in that area by extracellular inulinase activity of the strains. The reason that $\mathrm{Km} 7$ exhibited greater inulinase activity than $\mathrm{Km} 8$ may possibly be because microscopic examination showed that the $\mathrm{Km} 7$ inoculation resulted in denser colony growth than the $\mathrm{Km} 8$ inoculation. The area of cell growth was stained purple because numerous cellular components, such as glycogen, 
fungal walls, basement membrane, certain epithelial sulfomucins and sialomucins, and neutral mucosubstances, give a positive reaction with PAS. Inulinase activity was quantitated by HPLC measurement of the amount of fructose released by degradation of inulin. Both mutant strains $\mathrm{Km} 7$ and $\mathrm{Km} 8$ gave a value of $3.7 \mathrm{IU} / \mathrm{mL}$ for inulinase activity at $6 \mathrm{~h}$, which is comparable to values reported in the literature $[31,37]$.

These results suggest that the optimized $K$. marxianus mutant strains NRRL Y-50798 (Km7) and NRRL Y-50799 (Km8) produced by irradiation of K. marxianus NRRL Y 1109 also exhibit inulinase activity. Future work will involve an assessment to determine the type of inulinase secreted by each of the strains. These K. marxianus mutant strains, especially $\mathrm{Km} 7$, have the potential to be used to help remediate inulin-containing fruit and vegetable processing wastes such as those from coffee and tequila production [19, 24]. Inulin and inulin-containing materials also represent renewable and inexpensive and abundant feedstock for bioprocessing to produce valuable fuels and chemicals [3, 18]. The $K$. marxianus mutant strains have potential application in fermentation of inulin-containing plants as well as inulin-containing food and plant waste for an integrated biorefinery platform.

Acknowledgments The authors gratefully acknowledge the financial support of the Organization of American States for this research work.

\section{Complicance with ethical standards}

Conflict of interest The authors declare that they have no conflict of interest.

Open Access This article is distributed under the terms of the Creative Commons Attribution 4.0 International License (http://creativecommons.org/licenses/by/4.0/), which permits unrestricted use, distribution, and reproduction in any medium, provided you give appropriate credit to the original author(s) and the source, provide a link to the Creative Commons license, and indicate if changes were made.

\section{References}

1. Alonso E, Torrado A, Rúa ML, Pastrana L, Guerra NP (2014) Recovery and biotechnological production of high value-added products from fruit and vegetable residues. In: Teixeira JA, Vincente AA (eds) Engineering aspects of food biotechnology. CRC Press, Boca Raton, pp 328-356

2. Bonilla-Hermosa VA, Duarte WF, Schwan RF (2014) Utilization of coffee by-products obtained from semi-washed process for production of value-added compounds. Bioresour Technol 166:142-150

3. Chi ZM, Zhang T, Cao TS, Liu XY, Cui W, Zhao CH (2011) Biotechnological potential of inulin for bioprocesses. Bioresour Technol 102(6):4295-4303. doi:10.1016/j.biortech.2010.12.086

4. Dien BS, Casler MD, Hector RE, Iten LB, Nichols NN, Mertens JA, Cotta MA (2012) Biochemical processing of reed canarygrass into fuel ethanol. Intl $\mathrm{J}$ Low-Carbon Technol 7:338-347

5. Esquivel P, Jiménez VM (2012) Functional properties of coffee and coffee by-products. Food Res Int 46(2):488-495 Special issue: Schieber A (ed.), Functional foods and nutraceuticals

6. Gao J, Chen L, Yuan W (2012) Effects of carbon sources, oxygenation and ethanol on the production of inulinase by Kluyveromyces marxianus YX01. J BioSci Biotech 1(2):155-161

7. Gao J, Yuan W, Li Y, Xiang R, Hou S, Zhong S, Bai F (2015) Transcriptional analysis of Kluyveromyces marxianus for ethanol production from inulin using consolidated bioprocessing technology. Biotechnol Biofuels 8:115. doi:10.1186/s13068-015-0295-y

8. Hadj-Taieb N, Tounsi H, Chabchoub A, Abid N, Gargouri A (2011) Studies on the zymogram method for the detection of pectinolytic activities using CTAB. Appl Biochem Biotechnol 165(7-8):1652-1660. doi:10.1007/s12010-011-9384-y

9. Hong SJ, Kim HJ, Kim JW, Lee DH, Seo JH (2015) Optimizing promoters and secretory signal sequences for producing ethanol from inulin by recombinant Saccharomyces cerevisiae carrying Kluyveromyces marxianus inulinase. Bioprocess Biosyst Eng 38(2):263-272

10. Hu N, Yuan B, Sun J, Wang SA, Li FL (2012) Thermotolerant Kluyveromyces marxianus and Saccharomyces cerevisiae strains representing potentials for bioethanol production from Jerusalem artichoke by consolidated bioprocessing. Appl Microbiol Biotechnol 95(5):1359-1368. doi:10.1007/s00253-012-4240-8

11. Hughes SR, Bang SS, Cox EJ, Schoepke A, Ochwat K, Pinkelman R, Nelson D, Qureshi N, Gibbons WR, Kurtzman CP, Bischoff KM, Liu S, Cote GL, Rich JO, Jones MA, Cedeño D, Doran-Peterson J, Riaño-Herrera NM, Rodríguez-Valencia N, López-Núñez JC (2013) Automated UV-C mutagenesis of Kluyveromyces marxianus NRRL Y-1109 and selection for microaerophilic growth and ethanol production at elevated temperature on biomass sugars. J Lab Autom 18(4):276-290

12. Hughes SR, López-Núñez JC, Jones MA, Moser BR, Cox EJ, Lindquist M, Galindo-Leva LA, Riaño-Herrera NM, RodriguezValencia N, Gast F, Cedeño DL, Tasaki K, Brown RC, Darzins A, Brunner L (2014) Sustainable conversion of coffee and other crop wastes to biofuels and bioproducts using coupled biochemical and thermochemical processes in a multi-stage biorefinery concept. Appl Microbiol Biotechnol 98(20):8413-8431

13. Kim S, Park JM, Kim CH (2013) Ethanol production using whole plant biomass of Jerusalem artichoke by Kluyveromyces marxianus CBS1555. Appl Biochem Biotechnol 169(5):1531-1545

14. Lane MM, Morrissey JP (2010) Kluyveromyces marxianus: a yeast emerging from its sister's shadow. Fungal Biol Rev 24(1-2):17-26

15. Lane MM, Burke N, Karreman R, Wolfe KH, O’Byrne CP, Morrissey JP (2011) Physiological and metabolic diversity in the yeast Kluyveromyces marxianus. Antonie Van Leeuwenhoek 100(4):507-519. doi:10.1007/s10482-011-9606-x

16. Lashermes P, Andrade AC, Etienne H (2008) Genomics of coffee, one of the world's largest traded commodities. In: Moore H, Ming R (eds) Genomics of tropical crop plants. Springer, New York, pp 203-226

17. Lertwattanasakul N, Rodrussamee N, Suprayogi Limtong S, Thanonkeo P, Kosaka T, Yamada M (2011) Utilization capability of sucrose, raffinose and inulin and its less-sensitiveness to glucose repression in thermotolerant yeast Kluyveromyces marxianus DMKU 3-1042. AMB Express 1:20. doi:10.1186/2191-0855-1-20

18. Li L, Li L, Wang Y, Du Y, Qin S (2013) Biorefinery products from the inulin-containing crop Jerusalem artichioke. Biotechnol Lett 35:471-477

19. López-Alvarez A, Díaz-Pérez AL, Sosa-Aguirre C, MacíasRodríguez L, Campos-García J (2012) Ethanol yield and volatile 
compound content in fermentation of agave must by Kluyveromyces marxianus UMPe-1 comparing with Saccharomyces cerevisiae baker's yeast used in tequila production. J Biosci Bioeng 113(5):614-618

20. Mavumengwana, VB (2004) Isolation, purification and characterization of inulin and fructooligosaccharides from Chicorium intybus and inulinase from Aspergillus niger. MS thesis, Rhodes University, pp 47-48

21. Meenakshi S, Umayaparvathi S, Manivasagan P, Arumugam M, Balasubramanian T (2013) Purification and characterization of inulinase from marine bacterium, Bacillus cereus MU-31. Indian J Geo-Mar Sci 42(4):510-515

22. Murthy PS, Naidu M (2012) Sustainable management of coffee industry by-products and value addition-a review. Resour Conserv Recycl 66:45-58

23. Mussatto SI, Machado EMS, Carneiro LM, Teixeira JA (2012) Sugars metabolism and ethanol production by different yeast strains from coffee industry wastes hydrolysates. Appl Energ 92:763-768. doi:10.1016/j.apenergy.2011.08.020

24. Mussatto SI, Machado EMS, Martins S, Teixeira JA (2011) Production, composition, and application of coffee and its industrial residues. Food Bioprocess Technol 4:661-672

25. Mussatto SI, Teixeira JA (2014) Coffee. In: Teixeira JA, Vincente AA (eds) Engineering aspects of food biotechnology. CRC Press, Boca Raton, pp 413-428

26. Muthuselvi S, Sathishkumar T, Kumaresan K, Rajeshkumar M (2012) Improved inulinase activity by Penicillium purpurogenum grown in microwave pretreated coffee spent by L16 orthogonal design of experiment. Innovative Romanian Food Biotechnology 11:44-50

27. Neagu (Bonciu) C, Bahrim G (2011) Inulinases-a versatile tool for biotechnology. Innov Romanian Food Biotechnol 9:1-11

28. Pandey A, Soccol CR, Nigam P, Brand D, Mohan R, Roussos S (2000) Biotechnological potential of coffee pulp and coffee husk for bioprocesses. Biochem Eng J 6(2):153-162

29. Pandey A, Soccol CR, Selvakumar P, Soccol VT, Krieger N, Fontana JD (1999) Recent developments in microbial inulinases-its production, properties, and industrial applications. App Biochem Biotechnol 81:35-52

30. Pessoa A Jr, Vitolo M (1999) Inulinase from Kluyveromyces marxianus: culture medium composition and enzyme extraction. Braz J Chem Eng. doi:10.1590/S0104-66321999000300003

31. Rawat HK, Ganaie MA, Kango N (2015) Production of inulinase, fructosyltransferase and sucrase from fungi on lowvalue inulin-rich substrates and their use in generation of fructose and fructo-oligosaccharides. Antonie Van Leeuwenhoek. doi:10.1007/s10482-014-0373-3

32. Saha BC, Iten LB, Cotta MA, Wu YV (2005) Dilute acid pretreatment, enzymatic saccharification and fermentation of wheat straw to ethanol. Process Biochem 40:3693-3700

33. Singh RS, Dhaliwahl R, Puri M (2007) Production of high fructose syrup from Asparagus inulin using immobilized exoinulinase from Kluyveromyces marxianus YS-1. J Ind Microbiol Biotechnol 34:649-655

34. Tomita F (2003) Endophytes in Southeast Asia and Japan: their taxonomic diversity and potential applications. Fungal Divers 14:187-204

35. Valencia NR, Franco DAZ (2010) Los subproductos del café fuente de energía renovable. Avances Técnicos Cenicafé No. 393. http://biblioteca.cenicafe.org/avt0393. Accessed 7 Oct 2015

36. Van den Ende W (2013) Multifunctional fructans and raffinose family oligosaccharides. Front Plant Sci 4:247. doi:10.3389/ fpls.2013.00247

37. Yuan WJ, Chang BL, Ren JG, Liu JP, Bai FW, Li YY (2011) Consolidated bioprocessing strategy for ethanol production from Jerusalem artichoke tubers by Kluyveromyces marxianus under high gravity conditions. J Appl Microbiol 112:38-44

38. Yuan WJ, Zhao XQ, Ge XM, Bai FW (2008) Ethanol fermentation with Kluyveromyces marxianus from Jerusalem artichoke grown in salina and irrigated with a mixture of seawater and freshwater. J Appl Microbiol 105(6):2076-2083. doi:10.1111/j.1365-2672.2008.03903.x 